\title{
KAITIAKITANGA IN TE WĀI POUNAMU: Resource Management in a New Environment
}

\author{
Jim Williams \\ School of Maori, Pacific and Indigenous Studies, University of Otago, New Zealand
}

Copyright $(2016$ by authors, all rights reserved. Authors agree that this article remains permanently open access under the terms of the Creative Commons Attribution License 4.0 International License

\begin{abstract}
The paper argues that by the time of European contact Ngāi Tahu, the southernmost Māori had developed a regime of sustainable practices for the management of natural resources. Some of these practices are described. As traditional society, in the south, is located in a rather different cultural milieu than that occupied by Māori who lived in areas where kūmera harvests were reliable, an attempt is made to position Southern Ngāi Tahu in relation to the dominant anthropological paradigms, as an agricultural people may seem to have regressed to become primarily hunters and gatherers.
\end{abstract}

Keywords. Kaitiakitanga, Māori Natural Resource Management, Ngāi Tahu (Tribe of Southern New Zealand)

Tāria atu ana tai timu, ana tai pari. Wait until the tide has gone full cycle. (Good things come about in the fullness of time.)

(Ngāi Tahu proverb)

\section{Introduction}

Professor David L. Clarke of Cambridge University, in his seminal text Analytical Archaeology [1], pointed out that cultures are adaptations to a specific environment, such that a change of environment will normally be followed by some cultural adjustment. It is tempting to suggest, therefore, that the more dramatic the change in environment, the greater the cultural change. It happened that in Te Wāi Pounamu, Southern New Zealand a group of Polynesian agriculturalists once again became hunters and gatherers.

South of Banks Peninsula, where kūmera harvests were unreliable, an alternative economy developed in pre-contact times. As Garven, et al. point out "Over the centuries, a different system of resource management suited to New Zealand conditions was developed" [2]. This resulted from a combination of harsh climate and "rain-shadow" flora and lead to social modifications with the emergence of a unique regime of management processes that seem to have been continued by the later arrivals. It is the admixture of these groups that we now refer to as the "Southern Ngāi Tahu". This paper describes those Indigenous strategies and techniques that may be described as local adaptations of stewardship. In particular, the discussion focuses on access to resources, their husbandry including growth and harvest; preparation, distribution, storage and other management techniques. Husbandry is subdivided into practices of habitat enhancement, improvements to the quality of the stock, and limitations on harvests. The article will discuss each of these and conclude with some comments on the main bodies of theory that might be applied to the area of study. There is no attempt to prove the efficacy of the practices developed; rather, it is the strategy that is my focus, as they were believed to be effective and therefore rigidly adhered to. Many of the practices were employed elsewhere but there are others that are unique and the overall suite of practices was adapted to suit the area under review.

Tau et al. [3] describe the traditional relationship between NgāiTahu and their environment. To paraphrase: NgāiTahu developed over time a system of resource management appropriate to conditions in southern New Zealand through which careful observation and dependence had led to an advanced understanding of husbandry, habitats and breeding cycles of all fauna that were of value. Complex systems were established whereby resources were harvested at their seasonal optimum, then attention shifted and focused on another resource. NgāiTahu also developed unique technologies to store surpluses for long periods of time. The abundance and quality of the resources available to a tribal group directly determined their mana (presige), welfare and future. It was a straightforward reality that those with resources prospered and those without perished; therefore a top priority was appropriate management and maintenance through a rigorous system of controls. However, it will be seen that the associated ethic transcended purely economic considerations and became environmental in its focus. 


\section{Resource Management}

Davis, writing about the Menominee tribe, of Wisconsin, tells us:

Discussions of sustainability must deal with time. The issues of intergenerational equity and preservation are integral to any successful definition of sustainability. ... Eight components ... have to be studied. ... These include historic, legal, cultural, spiritual, ethical, political, technological/scientific, and economic aspects of Menominee life. All of these aspects are interrelated in complex ways that often defy precise description. Overlaying these aspects are the management principles and practices that have made the Menominee forest a sustainable forest environment $[4]$.

His point is important: that the actual management of resources operates within a context, and the context is as significant as the actions taken. Furthermore, the whole of the context needs to be regarded, since the efficacy of the actions is dependent upon the supporting mechanisms.

Whilst this paper predominantly examines the day to day, pragmatic interrelations between Ngāi Tahu, and their ecosystem, these must not be viewed as entirely secular activities since they were practised within a society where spiritual considerations permeated all. Accordingly, the underpinning principles must be kept in mind. Some central philosophical concepts, directly addressing resource management, are described below.

A new etymology developed, in accordance with local practice:

Kaihaukai

nga kai

mana whenua

Ritual distribution of surplus by exchanging specialty foods from one area to another, usually both obligatory and reciprocal;

Food preserve;

The right (and responsibility) to make decisions about the resources of a particular area;

Manawhenua Those who exercise mana whenua;

ohu Communal working bee;

piringa "Hangers on" (without resource rights, but with an expectation of ongoing support);

rauiri Reserved area;

wakawaka Division of a resource into sections, the rights to harvest each one being held by a different group ${ }^{1}$.

Many of these terms are underpinned by a different value system. For example, whilst ohu is very similar to the

\footnotetext{
${ }^{1}$ The word wakawaka is undoubtedly related to piwakawaka, the fantail, whose tail is similarly divided into long sections and also reflects the distribution of families on a multi-hull, voyaging canoe.
}

English term "working bee", there is a vital difference: all those involved in an ohu would expect to eventually draw some benefit from their efforts, though without necessarily contributing towards decisions about management of the resource. In other words they may be "piringa" rather than "Manawhenua". The work does not involve notions of community amenity. Similar cultural and social considerations involved in the other terms will be detailed below.

There are also some more general terms, which are involved in stewardship, but they are metaphysical concepts or "beliefs" rather than based on pragmatic considerations. The most important are: karakia (ritual incantations); mana (authority to act); mauri (life force; personality); tamatama (tribute paid to a superior from another location); and tapu (involving restrictions of a spiritual nature).

\subsubsection{Habitat Enhancement}

Natural processes do not necessarily create the optimal biotic mix. "Whilst nature produces all the individual elements, human ingenuity can mix them in ways that enhance ecosystems; produce new ones, or replicate ecosystems in places where nature cannot" [5]. Tūpuna (ancestors) observed nature, replicated the best patterns, and sometimes even improved upon them. For example, "Whānau planting" is the contemporary term for the age-old practice of planting associated species in clusters thereby establishing a "family of plants" [6]. Leakey and Lewin refer to such groves as "microecologies" wherein a symbiotic relationship exists between the various members of the community. The more varied the species in such a microecology, the greater the number of additional biota that will be attracted to it. Forest also controls light and water quality, and provides nourishment for the insects and snails that native fish feed on. When regeneration slows and the under-story is scant or absent, the water warms with exposure to light and becomes silted. The banks, where native fish hide and forage, break down; their habitat is gone, the forest is opened up to draughts, and the leaf litter dries out destroying the habitat of ground insects [7]. Powell [8] notes that the development of Kākahi, or fresh-water mussels (Hyridella spp), is dependent on larvae, known as glochidium, living for some time parasitically attached to certain species of fresh-water fishes, especially galaxids and Gobiomorphus, the giant bully. Reductions in habitat for these hosts would therefore reduce the range of the shellfish.

The ancestors were aware that stands of bush containing miro trees (Prumnopitys ferruginea) attracted kererū (wood pigeon; Hemiphaga novaeseelandiae) which came from a considerable distance to feed when the berries were ripe. Kererū are important seed dispersal vectors, and as they are broad-based feeders many species benefit from their presence. Put simply, in stands that include miro, regeneration of all species is faster. These are very likely the kinds of observations on which the concept of "whānau 
planting" is based, as it was deemed desirable to have rights to such a stand: "Kei a ia he oro miro, he rangatira hoki", (proverb).

\subsubsection{Improvement and Maintenance}

Environmental management did not only involve copying natural methods. Management practices focussed on the resource itself and the habitat required to produce optimal harvests. Indeed, huge efforts were put into improving certain habitats, and this could be either on-going or on a one-off basis. Freshwater seeding was facilitated by the use of "pouwhenua": logs placed in the water and often anchored. "Behind them were placed the kai [food] and catalysts for seeding" [9]. Folk on a quite unrelated journey, who found a log, or rock, near a stream, would be likely to drag it into the water to allow nature to take its course.

Hāpua, lagoons at the mouths of rivers, a feature of the Canterbury coastline, were periodically flushed of their silt to enhance the fishery [10]. Indeed, the paucity of mohoao, or black flounder (Rhombosolea retiaria), in Canterbury over the last few decades, is largely due to the pollution of the Te Waihora (Lake Ellesmere) gravel bottom (the preferred spawning ground of that species) due to silting and the resulting weed growth. This pollution has been considerably exacerbated by reduced water levels due to offtake for irrigation, stock and potable supply, and excess fertiliser from top-dressing which washes down feeder streams making the lake "highly eutrophic" [11].

Traditionally, every few years, ohu were called to open the lagoons, and these involved hapu (subtribes) over a wide area (see Figure 1). Interestingly, since 1990, "a change in the emphasis of lake level management from agricultural to ecological requirements" [11] has resulted in periodic flushings for ecological reasons, being reintroduced, underscoring the efficacy of traditional methods.

\footnotetext{
${ }^{2}$ A man is a chief indeed if he has a miro grove (as he will have plentiful resources).
}

\subsubsection{Te Waihora}

Fig. 1 is a French chart in the Canterbury Museum Archives (CMU2125). It was drawn during the 1848 visit of the corvette, "Le Rhin" and shows an outlet at the south end of Waihora. The chart carries a statement that the water body is opened to the sea, periodically, by the natives, to facilitate the taking of eels and waterfowl:

Grand Lac d'eau saumâtre, que les naturels font communiquer 'a volonté avec la mer, pour prendre des anguilles. Il est habité par une quantitié considérable de canards et de poules d'eau. ${ }^{3}$

Mantell and Bishop Selwyn each referred to this practice, thus:

"We passed the closed mouth of the Puarau ${ }^{4}$ lagoon which is occasionally opened by the Natives in the same manner as the Waihora" [12], Bishop Selwyn comments: "The mouth of waihora (sic) was dammed up but there is a place where a river occasionally breaks out into the sea from a heavy flood." [13].

Selwyn was an unreliable observer, inclined to jump to conclusions and, in particular, to deny human agency if he believed it unlikely that Māori had been responsible for certain acts.

Rewi Kōruarua, a $19^{\text {th }}$ Century kaumātua (elder), of Taumutu, tells the important story of Tūterakihuanoa, tupua ${ }^{5}$ and kaitiaki of Te Waihora and its resources ${ }^{6}$.The passage, which occupies approximately three pages of an eighteen page manuscript, outlines the care with which Waihora was from time to time opened lest Tūterakihuanoa, the caretaker, become angered and pollute the fishery. When the time came to open it, an ohu, comprising 50 to 100 men, performed the work and the whole population was put under certain restrictions, which was a way of reinforcing the importance of such practices [15].

\footnotetext{
${ }^{3}$ A large, brackish, fresh-water lake, which on occasions the natives open to the sea to facilitate the taking of eels. It is the habitat of considerable numbers of ducks and waterfowl (author's translation).

${ }_{4}$ Te Puarau is a few miles north of Timaru, but not as far as Opihi.

5 A tupua (or tipua) is the physical manifestation of an atua.

6 Tūterakihuanoa, also known as Tūterakiwhānoa, is also said to reside at other places, notably Waitarakao (Washdyke Lagoon).
} 


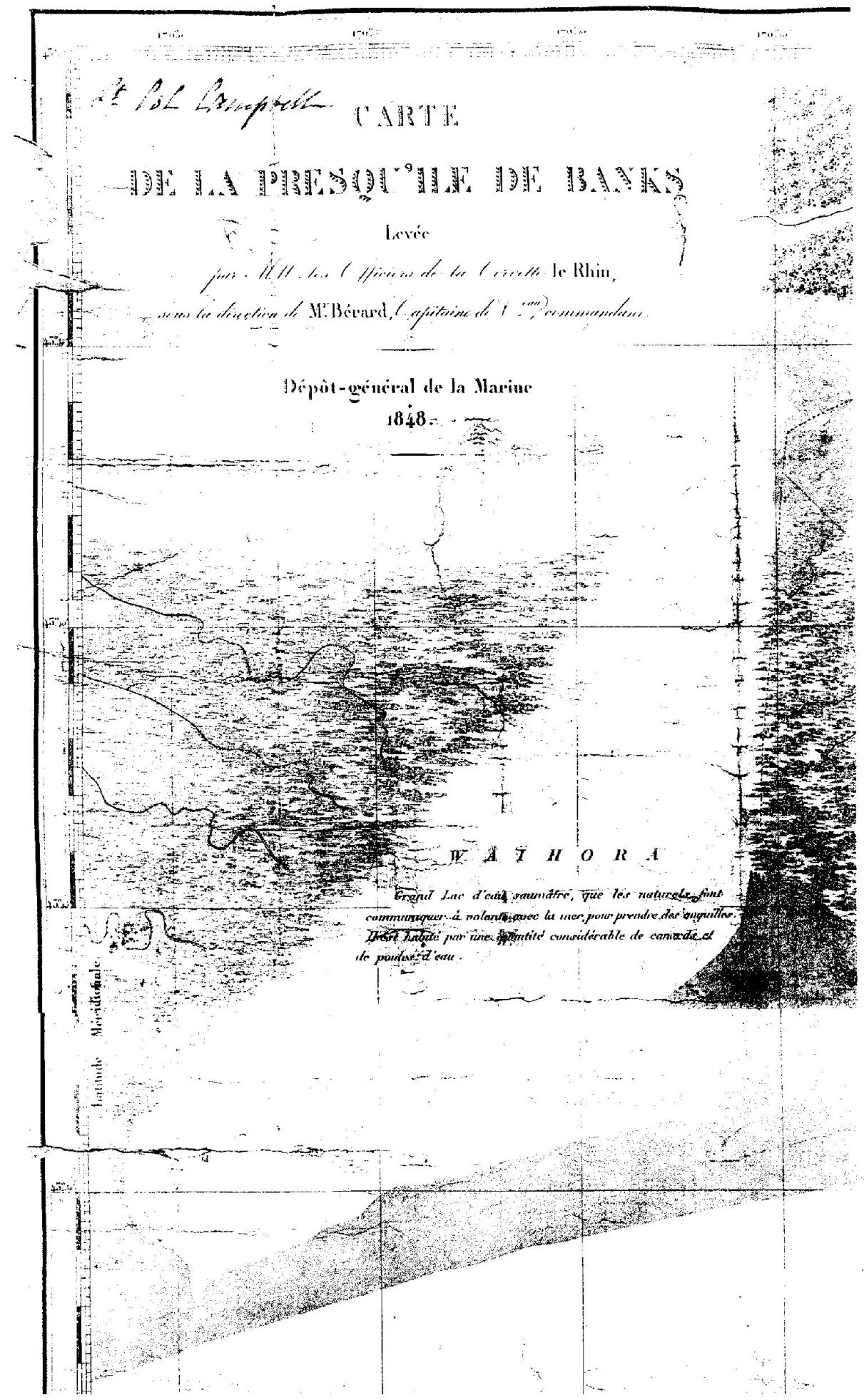

Figure 1. Te Waihora 1848 [14]

\subsubsection{Karengo}

Karengo (Porphyra columbina), an edible seaweed, only grows on certain types of rocks, none of which occur naturally south of the Clutha river mouth, yet I have been shown karengo on a large cluster of uniformly sized boulders in a small bay south of the Mataura. As the sea current along the coast is south to north, both the boulders and the alga could only have been brought in by human agency This suggestion is supported by the uniform size of the boulders: each is about as large as a strong man could carry to and from a canoe (Anon, 1999, Pers. $\mathrm{Com}^{7}$ ).

\footnotetext{
${ }^{7}$ To preserve confidentiality of this prized resource the informant has asked that both he and the location remain anonymous.
} 


\subsection{Population Improvement}

Māra mātaitai were seafood gardens and Garven et al. [2] report that seeding of shellfish beds was a feature of this type of husbandry: "Shellfish beds were seeded with superior strains taken and transplanted from other areas, and established beds were both enhanced and depleted by biological methods" (p.24).

Rakiihia Tau, in his evidence to the Waitangi Tribunal provides some examples.

Toheroa have been seeded at South Brighton/Karorokaroro (Pegasus Bay). These root stocks came from Kahuraki point (North of Westport) and Waikawa (Picton); similarly, tuatua in Pegasus Bay; cockles in Ihutai (Heathcote Estuary) ex Otepoti (Otago Harbour) and Kaikoura; scallop beds outside the North East bays of Akaroa [9].

Pōhā ${ }^{8}$ used to transport these "root stocks" were dropped in the inter-tidal zone and pricked with holes to allow slow release of spat. The pattern of holes would identify the whānau who had transported it; warning others not to interfere. Unquestioning adherence to the rules of society was the guarantee that such investments were safe.

Whilst cultural extensions have a purpose of their own, we must not lose sight of the fact that they had to be consistent with the primary objective: in this case, protection of the spat from predatory birds whilst permitting their gradual escape into the surrounding waters. The cultural function of recording ownership and discouraging potential interference could have more easily been carried out in other ways (e.g. "labeling" the pōhā with a bunch of feathers, as was done to record the contents of those going into storage) but the primary consideration was for holes to allow spat to escape. Therefore, it was a small matter to arrange them in a pattern that is at once practical, aesthetically pleasing and culturally helpful.

It is little wonder that seafood gathering areas were termed māra (gardens). As Thornton, et al. argue [16:189] marine resources are also "cultivated" in the American Northwest. However, it is difficult to accept "cultivation" as an appropriate term for fish - enhancement or management seems more apposite. "Gardening”'is preferred for sedentary seafood such as shellfish [17].

\subsubsection{Kurī}

Kurī, the Polynesian dog, was husbanded in traditional times. They were bred in captivity but inevitably some ran wild. When the breeding stock was depleted or when food was short, people would go on an excursion for new stock from the wild. Each rangatira, or chief, would be likely to keep 20 - 30 dogs in a good year [18]. Kurīwao ${ }^{9}$, near Clinton, in South Otago, is mentioned as one place where our ancestors were able to replenish their stocks, by capturing

\footnotetext{
${ }^{8}$ Bags made from the hollowed leaves of bull kelp (Durvillea antartica) ${ }^{9}$ Which means "wild dog".
}

wild dogs when stocks got low. A lactating female would be trapped, then permitted to escape so that she might lead the hunters to her lair. A male pup with desirable characteristics would be reserved for mating with the females; the other males being castrated (whakapoka), as they then fattened more quickly for the oven. Not only were they fattened for food, but their skins were also used for clothing, and dogs were trained to assist in getting weka, kākāpō and māunu (moulting ducks) during the annual duck drives (Beattie, nd(a) unpaginated).

Castration is a particularly interesting matter. It could be argued that it was management, or an enhancement technique, which set the ancestors apart from peoples who merely exploited their environment and is a significant contribution to the argument as the objective is manipulation of the gene pool. That the material is describing pre-contact practices can be attested through the use of the traditional word poka for castration (and the related term pokai tara was used for male sex offenders who had been emasculated [19]. Both indicate that the concept was, in fact, in vogue prior to European contact or else a transliteration would have been more probable ${ }^{10}$. Tarewai Wesley, Ngāi Tahu kaumātua (died, 1967) confirms this. He said that the weapon called wahaika ${ }^{11}$ was used in olden times to emasculate men found guilty of sexual offences against society. Khyla Russell, (1999, Pers. Com.) recalls a discussion in the 1950s during which Wesley imparted this information. ${ }^{12}$

However, dogs' testicles are not contained within an external scrotum and, accordingly, a fail-safe technique would have been required. The survival of small puppies would have been vital: we must assume that uncastrated males would have been preferable to a high death rate as an unacceptable death rate would certainly have militated against the procedure. "Farming" is appropriate for the husbanding of dogs.

Flora was husbanded in similar ways. Garven, et al. write:

Stands of trees such as karaka (Corynocarpus laevigatus) and tī kouka (Cordyline) were planted from selected stock, and were managed to optimise their production [2].

\subsection{Sustainable Harvest}

If by judicious kaitiakitanga a resource can have its mauri stimulated it will thrive, and the extra bounty can be harvested. Like māra moana, it is then freely available to the people. A good example of this is the harvesting of rimurapa (kelp) for pōhā. Maranuku (Kākā Point) was once renowned for pōhā kelp:

\footnotetext{
${ }^{10}$ Also, the practice is mentioned in the South Island story of Rona, the man in the moon. His wife's lover, Hoka, was emasculated and the cooked part fed to the adulterous wife. Legend is a fairly reliable reflection of societies' practices.

${ }_{11}$ Translates as fishes' mouth, a weapon of wood or bone, used in hand to hand fighting, and which often has a cutting surface of small shark's teeth.

${ }^{12}$ Taranaki elder, Sonny Waru, confirmed this traditional punishment of sex offenders at a youth health hui, in Hastings, in 1987.
} 
However, when Jimmy Bragg and Harold Ashwell returned to make poha there in 1986 [after many years, during which the kelp had not been harvested] they found the quality poor which supported their belief that the constant and prudent taking of kelp from an area produced better kelp rather like pruning a tree produced better fruit [20].

An examination of traditional harvesting methods provides further examples of wise resource management that would have ensured sustainability of renewable resources.

Goodall, in Taylor advises:

Harvesting methods reflect a thorough understanding of the breeding cycles, migration times and feeding habits of all the fresh and salt-water species of utilitarian value; with different names being used for the same fish at different stages of its life-cycle. Many species could be harvested at different times of year by understanding their habits at those times and adjusting the catching method to suit [11:32].

Pond agrees. She instances fish harvests "at stages in the life cycle when they are nutritious, being rich with roe; and at stages in the lunar cycle when they are abundant, congregating to migrate" ([7:83].

That Māori understood, and many still understand, the correspondence between lunar cycles and fish life cycles, and exploited that knowledge, is attested (inter alia) by the fish names, as attested by Pond:

Maori names mark those points where simultaneous changes in habitat, appearance, and habits bring about an identity-crisis ... whitebait (Galaxias maculata) however, enter streams from the sea in spring as unpigmented juveniles named karawaka; adults live solitary in the upper reaches and then migrate back downstream to spawn as inanga. The early run of inanga migrating downstream to spawn in the autumn is pukoareare; the major migration is matuaiwi [7:83].

Between their migration upstream as juveniles (karawaka or, in the south, mata), and their return to tidal reaches to spawn, they are distinguished according to criteria similar to the Linnean system used by western scientists: koaro, kōkopū, koukoupara, pippiki and ruao [21]. Further division is indicated by "ngaruru; second stage" (ibid.), presumably meaning that a post-fry/pre-adult stage was also recognized.

\subsubsection{Restricted Access}

In traditional society, access to resources could be restricted in three ways: temporally, by the imposition of seasons, spatially, by means of rauiri or wakawaka and by restricting some foods to certain people.

\subsubsection{Rāhui}

$\boldsymbol{R} \bar{a} \boldsymbol{h} \boldsymbol{u} \boldsymbol{i}$ was the ritual setting aside of a resource. It could be for a set time or an indeterminate period and it may be that the resource was reserved for an upcoming special occasion, or given time to regenerate after overuse. Some rāhui were seasonal; thus, kiore and ducks were not taken until the rāhui had been lifted [21] and \{22:366], and the tîtī (muttonbird) islands were not, indeed are still not, visited between the end of May and the following March. This is akin to the "Duck Shooting season", whereby in New Zealand ducks are placed under rāhui from the first of July until the first Saturday of the following May. An rāhui of a given food preserve was indicated by a warning sign, usually a small display of some item associated with the resource under restriction. So, if a bunch of kererū feathers were seen hanging beside the path into a particular forest then all who entered the area would be able to infer that kererū may not be taken there.

We can occasionally become distracted by spiritual considerations; rāhui was, and still is simply a practical consideration. Răhui was not due to the sanctity of the resource; it was a purely human consideration, imposed by humans to ensure the sustainability of the resource.

Similarly, rāhui were placed on areas frequented by birds, during their mating season [23:37]. This form of rāhui is still employed on the Tîtî Islands. The principle outlined here is typical of seasonal rāhui that are automatically renewed through common knowledge. An excellent example is the way in which the male kōkō (tui) became tute and females become kōkōtea during the breeding season (from the time of flowering of the kōtukutuku (October) until the fruiting of the hīnau (March)), as tūī hatch three clutches of eggs most summers but do not take permanent mates. Such a name change facilitated a ban on taking females during this period yet did not deny their existence as kōkō, which could be eaten, at other times [24].

Other rāhui were longer-term restrictions. Such "might be applied to a single tree that was to be preserved for a specific purpose" (such as to make a canoe or for bird spears). "Here the restriction might apply for generations" [23:37].

\subsubsection{Owheo}

Huata Holmes, a prominent southern Ngāi Tahu kaumātua, gave testimony to The Waitangi Tribunal on 27 July 1988 that "Owheo" was a conservation measure to allow land or water to remain unchanged. It could not be cleared or burnt, or have houses or weirs constructed there. Unlike rāhui, which are usually temporary restrictions, owheo were permanent and applied to all species. Holmes advised that he had been given this information in 1947 by the late Te Ari Pitama and Mahure Manawatu. The stream, in Dunedin, known as the Leith, is Owheo in Māori as it was permanently under this prohibition. A number of local families still do not take resources from the Leith catchment, or eat any taken by others (Khyla Russell, 2000, Pers. Com.).

\subsubsection{Wakawaka}

The difference between rauiri and wakawaka is partly a matter of local usage but, usually, rauiri refers to isolated food preserves to which a particular descent group has sole rights; wakawaka is the more usual term where a large 
resource is apportioned into discrete areas for each of several descent groups. Beattie describes how Tawera (Mount Oxford) was so divided for the taking of kiore (Polynesian rat): "The district was divided among hapus into wakawaka (sections) named after the tipunas, even as were the titi wakawaka on Titi Islands" [25:353].

Anake Goodall refers to a note by Tikao, that at Te Waihora

... each hapu had its own specific area to use - they certainly would not go to another hapü's locality without authority." ... This form of resource allocation and management - known to Ngāi Tahu as wakawaka still continues at Wairewa (Lake Forsyth) today ... [11:148], his emphasis.

It may consist of "family" drains dug into the sand spit to facilitate catching of tuna (eels) or the old practice of duck drives, in the moulting season (manu mounu), where each group had its own yard built along the edge of the lake, rather like a string of sheep-yards. The ducks, which could not fly when moulting, were driven along the surface of the lake in large numbers and each group closed the gate on the ducks that entered their yard [21]. That way, everybody got a share from the group effort to harvest what was a plentiful, but widely, distributed resource.

\subsubsection{Tapu}

Tikao informs us that if an ancestor was named for a bird or fish then descendants didn't eat that bird or fish [26:143), and "A woman said that she knew shags were caught near Temuka and eaten. Her father would not eat shags (koau) as the name was in his whakapapa" [18:14]. There are people living today who still observe this restriction though, admittedly, the majority has abandoned it. It may seem that as families ramified this tikanga would eventually result in the food being proscribed for all but the restriction did not apply to rights to that food which were inherited through other ancestors. Another apparent difficulty concerns Kāti Kurī. It might seem that by naming their son Kurī, his parents were effectively prohibiting their descendants from eating dog-meat for all time. However, another tikanga (prescription) takes precedence: dogs and humans are descendants of the same atua (Irawaru, progenitor of dogs, was originally a human). It is only when humans wish to use resources from the domain of another atua that ritual restrictions apply.

The restriction on eating food with the same name as one's ancestor is similar to the "taboo" in Fiji, mentioned by Veitayaki, where groups were prohibited from eating their totem species. As he says: "Exploitation is thus restricted" [27:120].

Not all economic species were seen to be in need of careful harvesting. For example, weka (see Beattie [28:43], quoting Tunuku Karetai): "We caught the weka with dogs and got two horse loads." However, Beattie goes on to report: "About 1895 poison was laid for the rabbits over all the runs and killed the wekas in thousands, so the Maori annual trips ceased about the turn of the century". The large $19^{\text {th }}$ Century harvests of weka are confirmed in several reports: "three tons of weka taken from Mackenzie Country in 1869" [29:37] and again in 1899 [30], though it would seem that Taylor may have got the date wrong. Significantly, Tikao says that there were no natural boundaries for weka [21:136], suggesting that, despite the importance of weka as food, natural conditions so favoured weka that conservation practices were not necessary. Practice in traditional society was predicated on the needs of the resource rather than its economic significance. Such species-specific rules exhibit knowledge of population biology: recruitment, off-take and harvesting rates.

\subsection{Other Management Practices}

In traditional times harvesting of most resources focused on mid-size individuals. Not only did the first fish caught go back to Tangaroa (deity of fish), so did many an oversize specimen. Any species not actually being sought ${ }^{13}$ would usually go the same way. The only regular exception of which I am aware is kōkopu, in which case the larger ones were taken. The fact that it was an exception is attested by the whakataukī: "Ka hika tā Kāti Mamoe, he kōkopu nui", When Kāti Mamoe kill it's a large issue, just like with kōkopu where only a big one is worth harvesting (in direct contrast with most other foods). The point in the metaphor and the underlying message is that this is an exception to normal practice. The underpinning philosophy is explained as follows:

However, great care was taken to ensure that only the excess of young birds and fish were taken, leaving the breeding stock, and thereby sustaining the resource. This system is analogous to "modern" livestock farming systems where the welfare of the capital stock is always considered paramount [2:23].

The importance of doing things in a particular way was emphasised by a prohibition on sexual relations during the harvesting season for many resources, notably most forms of deep-sea fishing and the harvesting of kāuru (cabbage tree sugar) [31]. The rationale was that a man's tapu was reduced during intercourse and his mauri weakened. Western Science tells us that orgasm results in an increase in endorphins which create a sense of well-being, a similar effect to morphine [32:246]. In turn, endorphins stimulate the production of adrenaline (Cape 1964:8). It is probably significant that no such restriction seems to have been placed on warriors about to do battle - where increased adrenaline levels were probably an advantage - suggesting a good knowledge of human physiology and the relationships between actions and bodily reactions. As with metaphysical matters (karakia and ritual aspects), the ban on intercourse

13 When fishing, the ancestors went out for a particular species. The fishing ground, tackle and methods, all being geared towards the specific catch anticipated. 
would have helped to elevate harvesting activities above the mundane, creating a climate of particularity to reinforce the special nature of the activity.

It must not be assumed that there were no exceptions to normal practices if the exigencies of the situation warranted them. In times of hardship, rules could be relaxed, but only those with the authority to enforce rules were entitled to vary them. This would only happen after consultation with tohuka - those in whom the knowledge of the people had been invested - so that when and if required the entire knowledge base of the people would be available to underpin crucial decisions. If in doubt the question would have been: "is the present risk to the group sufficient to justify placing the resource base itself at risk?" Such was the fabric of traditional society that only those trained for such a decision would ever contemplate making it, and karakia would have been required to mediate with the appropriate atua.

\section{Settlement Types}

A reformed social organisation, dictated by the environment in which sustaining resources are harvested, evolved over time. The palisaded pā (fortress), or Pā Tūwatawata that had become so prominent during agricultural times, remained a central, if rather less common, feature - perhaps for reasons associated with military security: a safe place for the very old and very young, shared by all at times when there was no wholescale harvesting in progress. These were suitable repositories for the storage of surplus and for stocks of pounamu (greenstone), which the elderly would work on when not occupied by more immediate concerns.

The Mahinga Kai data in Taiaroa [33] contain references to three further categories of settlement, in increasing order of permanence: "Kainga Mahika Kai", "Kainga Nohoanga" and "Kainga Nohoanga Tuturu". The permanence of the site depends upon how regularly it is used. Most, but not all, Kainga Nohoanga Tuturu refer to an urupā (cemetery), so we can therefore infer five levels of settlement: Kāinga Mahika Kai or occasional camping places which were not maintained continuously and could be visited as seldom as five-yearly; Kāinga Nohoanga or regular, annual camping places, probably with rudimentary dwellings which would be maintained at each visit ${ }^{14}$; Kāinga Nohoanga Tūturu or semi-permanent settlements, the most important of which were associated with urupā, thus committing the people to regular attendance, probably several times each year; and Pā Tūwatawata or palisaded forts always with urupā and a small number of permanent inhabitants. The majority have gardens and tūāhu (special places, where karakia (incantations) were

14 In his testimony (No. 36) to the Smith/Nairn Commission (N. A.; MA 67/4:17-18) missionary J.W. Stack describes a Kāinga Nohoanga as any place with both a dwelling and a pataka (storehouse). Neither on its own was deemed evidence of regular residence. recited to call on ancestral support). Some Kāinga Nohoanga Tūturu also had gardens, and/or tūāhu. Pahuri were temporary shelters (that may be likened to bivouacs), used at non-permanent camps, [34:19]. Pahuri would be titivated up each season and re-occupied. Taiaroa [33] lists, by type, 1811 settlements where some 114 different resources were harvested, the majority being sources of protein.

\subsection{Preserves}

Harvesting areas were both defined and named. Koutu aruhe; para kauru; mara mahetau/taewa, or pora; matatiki, pā, rē, or rauiri tuna; tapua weka; werohanga or taheretanga manu. These are, respectively: fern-root "digs"; cabbage tree groves; cultivations of vegetables; eel springs, weirs, swamps or preserves; weka runs; bird spearing or snaring groves. Each term refers to the fact that rights gained through whakapapa descent are involved, each being effectively a "preserve" with the different terms reflecting the different natures of each type of preserve. Koutu aruhe and mara are quite localised, though not as localised as a rauiri tuna, which would be a very specific location on a stream whereas the garden could shift around at the locality. There is no term given for harakeke (flax) cultivations. A tapua weka would be rather more extensive, though not as large as a para kauru, which might cover many acres. These preserves often had their own names, rather like contemporary farm names (e.g. in [33 List 11, page 4]: "E Mahinga tuna [named] Ko te Whakahoki a Paroro").

\section{Conclusions}

An environmental ethic is largely a matter of the attitude towards nature inherent in the individual. I recall my poua (grandfather) telling me, in the late 1950s, "there are also mountain trout, native ones [kōkōpu], in certain places, but I'm not going to show you where they are as there aren't enough of them left to eat them any more" (Jack Burgess, Kōrero-ā-waha). It's not as if he was strongly Māori in the way he lived his life, but certain attitudes consistent with traditional Māori thought remained.

\subsection{The Main Blocks of Theory}

In reviewing the theoretical base of this research, we should re-examine the theoretical models and measure the extent to which the subject matter of the paper fits known paradigms. As a people move from one type of society to another they will take certain aspects of their previous life-style with them. So, the small amounts of agriculture practised by the Southern Ngāi Tahu is not a move towards agriculturalism but a skill retained from when they lived in a climate better suited to agriculture. So, when Europeans introduced potatoes, in the late $18^{\text {th }}$ century, they were promptly embraced. 


\subsubsection{Ecological Theory}

Amongst ecological theories, Leopold refers to the notion of ecological chains and their interdependencies. Humans are, he says, "the only entity that have the ability to reorganise or disorganise the chains" [35:225]. That Māori recognised the inter-relatedness of species, and managed accordingly, is seen in the example of the use of whelks to improve shellfish beds by eating the weaker ones. Leopold further suggests that an ecological conscience is the ethic of positive reorganisation of these chains and that the mechanism of control "is the same as for any ethic: social approbation for right actions: social disapproval for wrong actions" (ibid.). Māori in pre-contact Te Wāipounamu acted in just such a manner, with strong social controls and disapproval for wrong action. Rāhui was one such social control.

\subsubsection{Anthropological Theory}

Anthropological theory relevant to this study is presently undergoing major re-evaluation. In particular, two recent volumes, one British and one American [36,37] provide advances in academic thinking in several areas. This thinking is now influenced by the realisation that much former work was of an essentially etic perspective. New dimensions, provided by insiders' understandings, are now influencing many interpretations.

\subsubsection{Hunter-Gatherer Theory}

Southern NgāiTahu does not seem to fit within current theories of hunter-gatherers. As Anderson has suggested [38], based upon their hierarchical hapu structure, they were atypical of band type social organisations.

\subsubsection{Optimal Foraging Theory}

Confections (kai rēhia) and foods such as tutu that were eaten primarily for taste rather than nutrition run counter to the suggestions of Optional Foraging Theory. Similarly, surplus distribution through kaihaukai is not consistent with that model. The essential differences are two-fold: firstly, southern Māori were a branch of a stratified Polynesian society; and the variety and plenitude of resources rendered hoarding and super-stringent harvesting unnecessary in many cases.

\subsubsection{Middle-range Theory}

Of the theories available, Middle-range Theory appears to offer the closest fit with this study. The people examined here were subject to significant seasonality with severe winters and a relatively short growing season. However, the model seems to assume a constant group structure rather than the NgāiTahu habit of breaking up and coalescing in differently constituted sub-groups. Whether or not this negates the theory is not clear.

\subsubsection{Food Storage and Exchange Theories}

Winterhalder notes: "most scholars have assumed that the basic economic features of hunter-gatherers influence their social, political, and other cultural behaviours" [39:33]. In the case of the southern NgaiiTahu this is the reverse of what happened: social and political behaviours are similar to their more northern relations, with relatively minor adaptations to fit the very different, local, economic features. It is the nature of economic production that has been tailored to suit the cultural features of the people. This is particularly so in the dilution of the hapū; the innovative, yet sophisticated, systems of resource allocation (such as the wakawaka system); and systems for distribution of surpluses, especially pōhā and kaihaukai.

$\boldsymbol{P} \overline{\boldsymbol{o}} \boldsymbol{h} \overline{\boldsymbol{a}}$, whilst not unknown in the north, seem to be a southern development, designed to facilitate storage and exchange as an adaptation to the needs and resources of the south. Further north, hue (gourds) were grown and used for these purposes, but they did not thrive in the colder southern climate. As a replacement, kelp pōhā were developed to facilitate the preservation and transport of food in greater quantities. Pōhā also facilitated transfer of large numbers of shellfish seeding stocks.

Kaihaukai, was a form of feasting, again known in the North Island but there is no evidence to suggest that it reached the prominence, and levels of reciprocity there that it did in the south. In particular, kaihaukai can be seen in the area under review to have been a means of distributing, from district to district, the significant and disparate surpluses that occurred.

Together, the southern development of pōhā and kaihaukai constitute strong evidence for the development of a distinctive sub-culture, based on features of the southern environment and the ensuing, different, conspectus of resources, used in ways unique to the south.

Testart [40:526] refers to the essential difference between gifting by groups with storage and hunters without storage facilities. The former, choose altruistically (aroha) to give away their surplus. They gain prestige through their generosity. The latter, unable to use amounts excess to their own needs, gain prestige as a hunter by gifting without suffering loss, yet in anticipation of a later gain when the gift is reciprocated.

Regional variation in foods, and the concomitant political organisations, reflect synergies built into the economy, allowing the flexibility that underpinned both the ability to harvest optimally and the freedom to take an ecological viewpoint. Otherwise, it is likely that neither would have been possible. The idea that storage leads to wealth being accumulated for reasons of prestige cannot be supported. As the Dene hunter related to Berger: "All I can put aside is in nature and it allows me to make a living. This is my bank. This is my savings account" [40:527].

\subsection{The Gene Pool}

If hunter-gatherers are characterised by an "absence of direct human control over the reproduction of exploited 
species" and "no deliberate alteration of the gene pool of exploited resources" [36:2], then the population in the area under review cannot be described as true hunter-gatherers. The paper describes general practices of population improvement and the castration of those male kurī pups adjudged to have less desirable features, all constituting deliberate manipulation of the gene pool. In addition, the practice of harvesting mid-size individuals of most species, rather than the larger adults, would have resulted in the culling of under-size adults, effectively selecting for larger breeding stock. However, whether this was deliberate or serendipitous is difficult to judge.

\subsection{Reversion?}

It is usually suggested that societies evolve, in the main, from an "earlier (or "lower stage") to a later (or "higher") stage" [42:8], However, they do allow that "regression is acknowledged as a possible (and sometimes actual) occurrence" (ibid.). Is that what we see here? In line with David Clarke's comment on the influence of environmental factors (see above), Ngāi Tahu did indeed revert to becoming "Hunters and Gatherers" but with a difference: those strategies learned during their Agricultural past were retained and a somewhat more sophisticated type of hunting and gathering was practised. "Husbandry" is suggested as the most appropriate descriptor for the ecosystem stewardship that was practised, but none of the extant paradigms are accurate.

\subsection{Kaitiakitanga}

The vital component of traditional Māori resource management is kaitiakitanga, a concept with two dimensions. On the metaphysical level it refers to the various ways in which atua are manifest to support the present generation; each atua being seen to have its own area of concern. On the practical level, the practice of kaitiakitanga requires the Manawhenua linked with resources in a particular locality, to mirror the kaitiakitanga of atua for the good of the entire descent group. Sustainability is key to the concept of kaitiakitanga.

Even plentiful foods were managed (apparently, with the exception of weka). There is ample evidence that whitebait were plentiful (e.g. [42, 43]), yet sustainability of this resource was ensured through careful harvesting. When netting, children were "given the task of separating and throwing back the females - easily distinguished by the dark stripe that keen young eyes could quickly pick out." [44:537]. The fisheries scientist, McDowall, advises that there is no evidence that the black-striped whitebait are female but this form of culling: a) allowed some whitebait to escape the harvest and b) enabled children to be taught a valuable conservation ethic. Over-exploitation was addressed on a larger scale. The Buller River was called Kawatiri. This name comes from the customary practice of declaring the river-banks "tapu" for several miles during runs.
When the fish were considered to have had sufficient time to advance beyond the tapu boundaries, sprigs of kawakawa were cut by the tohungas who then proceeded along the banks of the river in canoes striking the surface at regular intervals with their kawakawa twigs. The action of striking the water which had previously been declared tapu had the effect of removing the prohibition on fishing. When all the ceremonies were completed, an offering was made to the god (atua) of the river; the oblation was called 'tiri' [45:45-46].

General practices were observed as well, regardless of species, and provide evidence of a traditional attitude towards resources that had progressed beyond species specific practices based on observations of what was necessary for sustainability. It would seem that a conservation ethic was in place. For example, one must never gut fish or shuck shellfish below the high tide mark. This restriction was mentioned (albeit in a slightly different form) to Herries Beattie:

One old friend warned me: 'If you get paua (pawas), you must never kohiti (take them out of shell) at the place you get them, or leave the shells behind at that place. If you do it will become a real wahi-mahue (deserted place), for the living paua would desert there [28:33].

In each case the focus is not merely on respect for the resources, it is also inherent in the respect for and recognition of the need for sustainability, and ensuring that predators are not encouraged.

The management practices that evolved over time were accompanied by adaptations to the social structures, so that a more whānau-based society emerged and hapū became less significant, compared with the northern, agricultural tribes [46]. Indeed, a number of early Europeans commented on the fact that when asked their hapū, Ngāi Tahu would usually have a discussion before replying and the hapu claimed would change as they shifted from place to place (for example, [47]). This was to do with which ancestor resource rights at that place were inherited from. Actual practices would have evolved as the mâtauranga (knowledge) built up and certainly followed an initial period when errors were made due to a lack of knowledge. Nevertheless, by the time of European contact, Māori in the south had become fully in tune with the species in their environment, leading one to favour the definition of "cultivators" offered by Thornton, et al. [16:191] "conscious effort to create specific conditions for advantageous engagement and relations with another being". The extent that Ngāi Tahu had adapted was a reflection of their very different environment.

\section{Compliance with Ethical Standards}

The author declares that he has no conflict of interest.

The research was unfunded, did not involve persons or animals and informed consent was obtained from all 
informants.

\author{
Abbreviations \\ CMU Canterbury Museum Library and Archives, \\ Christchurch \\ Hock Hocken Archives, Dunedin \\ JPS Journal of the Polynesian Society \\ Ms. Manuscript \\ nd. no date quoted \\ np. no publisher \\ NZJA New Zealand Journal of Archaeology \\ ODT Otago Daily Times
}

\section{Oral Informants}

Anon; Ngāi Tahu, Kaumātua

Burgess, Jack (1895-1968); NgāiTahu, my poua

Russell, Khyla, (Dr.); NgāiTahu, Taua

Tau, Henare Rakiihia; NgāiTūahuriri, Kaumātua

\section{REFERENCES}

[1] Clarke, David L. Analytical Archaeology, Methuen, London 1963

[2] Garven, Peter, Nepia, Marty, Ashwell, Harold; Te Whakatau Kaupapa o Murihiku, Aoraki Press, Wellington, 1997:23

[3] Tau Te M., Goodall A., Palmer D., Tau, R.; Te Whakatau Kaupapa; Ngai Tahu resource management strategy for the Canterbury region, Aoraki Press, Wellington, 1990

[4] Davis, Thomas; Sustaining the Forest, the People and the Spirit, State University of New York Press, Albany 2000:9

[5] Dubos, Rene; The Resilience of Ecosystems, Colorado Associated University Press 1978:2

[6] Leakey, Richard and Lewin, Roger; The Sixth Extinction: Patterns of Life and the Future of Humankind, Doubleday, New York, 1995:240

[7] Pond, Wendy; The Land with All Woods and Water, Waitangi Tribunal Rangahaua Whanui Series, National Theme U, 1997:10-11

[8] Powell, A.W.B.; Shells of New Zealand, Whitcombe and Tombs, Christchurch, 1957

[9] Tau, H. R. Evidence to the Waitangi Tribunal (Wai 27, $\mathrm{J} 10: 10)$.

[10] W.B.D. Mantell 28.5.1849, letter to Colonial Secretary (cited in Mackay A Compendium of Official Documents relative to Native Affairs in the South Island. 2 vols, Government Printer, Wellington, 1873:224

[11] Taylor, K. J. W. (Ed.); The Natural Resources of Lake Ellesmere (Te Waihora) and its Catchment, Canterbury
Regional Council, Christchurch, 1996:1

[12] W.B.D. Mantell Journal, 17/10/1848, Alexandere Turnbull Library Ms papers 1535

[13] Selwyn, G. A. (Bishop); Journal 1843-1844, Typescript, Hock.

[14] Le Rhin map 1848; "Carte de la Presq'uile de Banks", Canterbury Museum Archives Ms 2125

[15] Kōruarua, Rewi,; Tuterakihuanoa, Ngāi Tahu Archive, Ms., MB140, Hii/1, Folio 3, nd.

[16] Thornton, Thomas, Deur, Douglas and Kitka, Herman Sr.; "Cultivation of Salmon and other Marine Resources on the Northwest Coast of North America", in Human Ecology, (2015) Vol. 43:189-199

[17] Williams, Judith; Clam Gardens: Aboriginal Mariculture on Canada's West Coast, New Star Books, Vancouver, 2006

[18] Anon Ngāi Tahu Archives MB140 Hii/ii, Folio 5, (Herries Beattie's handwriting) nd.

[19] Beattie, Herries; Hocken Ms 582/E/11, nd(c)

[20] Dacker, Bill; He Raraka a Ka Awa, unpublished typescript held by Kāti Huirapa Rūnaka, Puketeraki, 2000, page 36

[21] Strickland, R.R.; Nga Tini A Tangaroa, MAF Fisheries, Wellington, 1990

[22] Tikao, Teone Taare,; Mahinga Manu wai maori nd(b) (but certainly prior to 1870 )

[23] Best, Elsdon; Forest Lore of the Maori, Government Printer, Wellington, 1977

[24] Riley, Murdoch; Mäori Bird Lore; Viking Sevenseas, Paraparaumu, 2001

[25] Anon.; "Birds and Birdcatching", Ms, MB140, Hii/2, Folio 1, $\mathrm{nd}(\mathrm{b})$

[26] Beattie, Herries; Traditional Lifeways of the Southern Maori, Otago University Press, Dunedin, 1994

[27] Tikao, T. T.,; Tikao Talks, Penguin, Auckland, 1990

[28] Veitayaki, Joeli; 'Fisheries resource-use culture in Fiji and its implications', in Hooper, Anthony (Ed.) 2000, Culture and Sustainable Development in the Pacific, Asia Pacific Press, Canberra

[29] Beattie, Herries; Our Southernmost Maoris, ODT, Dunedin, 1954

[30] Andersen, J.C.; Jubilee History of South Canterbury, Whitcombe \& Tombs, Wellington, 1916

[31] Taylor, W. A; Lore and History of the South Island Maori, Bascands, Christchurch, 1950

[32] Tikao, Teone Taare,; Mahinga Kauru, Ms. papers 1187, Folder 208, nd(a) (but certainly prior to 1870)

[33] Collins; Concise Dictionary and Thesaurus, Harper Collins, Glasgow, 1991

[34] Taiaroa, H. K.; Mahika kai lists, Ms., MB 140, Hii/19, various folders, 1880

[35] Anderson, Atholl; Te Puoho's Last Raid, Otago Heritage Books, Dunedin, 1986 
[36] Leopold, Aldo; A Sand County Almanac, Oxford University Press, New York, 1987

[37] Panter-Brick, Catherine, Layton, Robert H., and Rowley-Conwy, Peter (Ed.s); Hunter-Gatherers: an interdisciplinary perspective, Cambridge University Press, Cambridge, 2001

[38] Fitzhugh, Ben and Habu, Junko; Beyond Foraging and Collecting, Kluwer Academic/Plenum Publishing, New York, 2002

[39] Anderson, A. J.; 'Towards an Explanation of Protohistoric Social Organization and Settlement Patterns Amongst the Southern Ngai Tahu', in NZJA 2:3-23 (1980)

[40] Winterhalder, Bruce; 'The behavioural ecology of hunter-gatherers', in Panter-Brick, et al., Hunter-gatherers: an interdisciplinary perspective, Cambridge University Press, Cambridge, 2001, P. 12-38

[41] Testart, Alain; "The Significance of Food Storage among Hunter-Gatherers: Residence Patterns, Population Densities, and Social Inequalities" in Current Anthropology, Vol. 23, No 5 (1982): $523-537$
[42] Sanderson, Stephen K. and Alderson, Arthur S.; World Societies: The Evolution of Human Social Life, Pearson, Boston, 2005

[43] McDowall, R. M.; The New Zealand Whitebait Book, Reed, Wellington, 1984

[44] McDowall, R. M.; Ikawai: Freshwater fishes in Māori culture and economy, Canterbury University Press, Christchurch, 2011

[45] Temm, P. B. Esq. Q. C.; 'Keynote address-NZIS Conference 1986', in N. Z. Surveyor, February 1987, Pages 533 - 540

[46] Mitchell, G. M. M.; Maori Place Names in Buller County, Reed, Wellington, 1948

[47] Williams, Jim; "Mahika Kai: The Husbanding of Consumables by Māori in Precontact Te Wāipounamu", in JPS, Vol. 119 (2) 2010:149-180

[48] Shortland, Edward 1851; The Southern Districts of New Zealand, Longman, Brown, Green and Longmans, London. 